\title{
Detailed iconography of the widespread Neotropical millipede, Myrmecodesmus hastatus (Schubart, 1945), and the first record of the species from the Caribbean area (Diplopoda, Polydesmida, Pyrgodesmidae)
}

\author{
Sergei I. GolOVATCH ${ }^{1}$, Jean-Jacques GEOFFROY ${ }^{2}$, Jean-Paul MAURIÈs ${ }^{3}$ \\ and Didier VANDENSPIEGEL ${ }^{4}$ \\ ${ }^{I}$ Institute for Problems of Ecology and Evolution, Russian Academy of Sciences, Leninsky pr. 33, \\ Moscow 119071,Russia; e-mail: sgolovatch@yandex.ru \\ ${ }^{2}$ Muséum national d'Histoire naturelle, DSE, Site MNHN de Brunoy, 4 avenue du petit Château, \\ 91800 Brunoy, France \\ ${ }^{3}$ Muséum national d'Histoire naturelle, Département Systématique \& Evolution, CP n53, 61 rue Buffon, \\ 75005 Paris, France \\ ${ }^{4}$ Muséum Royal de l'Afrique Centrale, Tervuren, B-3080 Belgium
}

\begin{abstract}
The small-bodied millipede, Myrmecodesmus hastatus (Schubart, 1945), which seems to be strongly associated with ant and termite nests, and currently populates much of South America, is recorded from Martinique for the first time. Abundant, mostly SEM illustrations are provided to facilitate its recognition. This record strongly extends its distribution to also cover the Antilles.
\end{abstract}

Key words: Diplopoda, Myrmecodesmus, myrmecophily, termitophily, synathropization, Neotropics

\section{INTRODUCTION}

The small-bodied, cryptic millipede Myrmecodesmus hastatus was first described as the type and only species of the genus Gonographis Schubart, 1945: G. hastata Schubart, 1945, from Distrito Federal, Brazil ( 1945). A little later, the same species was again described as new: Lophodesmus inquilinus Silvestri, 1947, from one locality in Argentina and two in Brazil (Silvestri 1947). Their formal synonymy was advanced by Schubart (1954).

Golovatch (2000) synonynymized Gonographis with Myrmecodesmus Silvestri, 1910, and the latter genus has become one of the largest within the family Pyrgodesmidae. At the moment, Myrmecodesmus has as many as 11 generic synonyms and more than 30 valid species, all American (Hoffman 1999). The distribution pattern is pan-Neotropical, ranging from Florida, Alabama, Missisippi, Louisiana and Texas in the USA in the north (Shelley 2004) to Argentina in the south. The bulk of Myrmecodesmus species diversity is confined to Central America together with the Caribbean, whereas only a few species inhabit southern North America and entire South America (Golovatch \& Adis 2004). However, in South America at least, in contrast to any congener, one of the four currently described species, viz., $M$. hastatus, has attained a particularly vast distribution, a fact presumably accounted for by its special ecological traits.

Known records of $M$. hastatus have been summarized and mapped (Golovatch \& Adis 2004). This species is remarkably widespread over much of South America, being associated with human settlements, plantations, gardens, as well as termitaria and ant nests in Brazil, Peru and Argentina. The records show clear-cut inclinations of M. hastatus to dwelling in open habitats, often if not always in association with ants and/or termites. In Myrmecodesmus, as 
implied by the generic name, there are several species that can be termed as formi- and/or termiticoles. Some of these, like numerous other myrmeco- or termitophiles, are indeed relatively widespread, especially when the host species of ant or termite occupies a wide geographical area (cf. Schubart 1947). This concerns at least M. formicarius Silvestri, 1910, known from Vera Cruz, Mexico north and east through the Texas coastal plain as far as Louisiana, U.S.A. (Hoffman 1999, Shelley 2004). However, M. hastatus appears to be especially widely distributed, ranging over much of South America from Amazonia in the north to northern Argentina in the south.

The present note puts on record the occurrence of M. hastatus as far north as the Antilles. In addition, the species is abundantly illustrated, including SEM micrographs, to facilitate its recognition.

\section{MATERIAL AND METHODS}

The underlying material comes from various places on Martinique, Lesser Antilles. As it was mostly represented by juveniles and females, it had remained unidentified until the quite recent collection of males.

All material treated here belongs to the collection of the Muséum national d'Histoire naturelle, Paris, France. The samples are stored in $70 \%$ ethanol. Specimens for scanning electron microscopy (SEM) were air-dried, mounted on aluminium stubs, coated with gold and studied using a JEOL JSM-6480LV scanning electron microscope.

\section{FAUNISTIC AND TAXONOMIC PART}

The following M. hastatus samples from Martinique are kept in the Paris Museum collection:

Material examined. 1 juv.: Les Anses d'Arlet, under stones $0.5 \mathrm{~km} \mathrm{~N}$ of Anses d'Arlet, 11 Nov 1978; 3 juv.: Grand'Rivière, near beach, Anse Morne Rouge, dead tree, 20 Feb 1981, all leg. J.-M. Thibaud; 3 females, 7 juv.: Gros-Morne, $6 \mathrm{~km} \mathrm{NE}$ of Gros-Morne, forest between Morne Bellevue and Morne de l'Etang, 600-690 m a.s.l., dead leaves and wood, 11 Feb 1981; 1 juv.: Trinité, near île Caravelle, under dry log between l'Oratoire and meteo station, 80-115 m a.s.1., 12 Feb 1981; 29 juv.: Morne Rouge, Trace des Jésuites, right bank of Lorrain River, 400-500 m a.s.1., dead wood and bamboo, 13 Feb 1981; 8 juv.: Rivière-Pilote, Anse Figuier, under bark of Cocos palm lying on sand, 24 Feb 1981; 1 juv.: Grand'Rivière, path to Morne Macouba (massif Montagne Pelée), S of savanna Anatole, forest, 550-600 m a.s.1., dead wood and leaves, 26 Feb 1981; 4 females, 2 juv.: Grand'Rivière, Morne aux Gueules (path to Montagne Pelée), cultivated land, 26.II.1981; 3 females: Fonds-Saint-Denis, Pitons du Carbet, between sides at 1100 and $1120 \mathrm{~m}$ a.s.l., SSE of Piton Boucher, bush savanna, mosses and dead wood, 27 Feb 1981, all leg. J.-P. Mauriès; 2 males, 9 juv.: Saint-Pierre, rocks, sugar cane, $80 \mathrm{~m}$ a.s.1., 02 Mar 2015, leg. M. Coulis.

Remarks. As seen from the above records, M. hastatus is remarkably widespread on Martinique, ranging from nearly sea-level to mountain tops above $1100 \mathrm{~m}$ in elevation. Although there are no direct observations on the labels of its association with ants or termites, dead wood in the tropics is known to be widely populated and destroyed by termites.

Both available males were studied in detail to reveal the species identity. The results are presented in Figs 1-20. There can be no doubt now that the Martinique samples belong to $M$. hastatus. The spinulate flagellum (fl) arising at the base of a simple, more or less sigmoid solenomere (sl) is especially characteristic (Figs 14-17 \& 20). SEM iconography demonstrates all features typical of a small cryptic pyrgodesmid, including a flabellate collum that fully covers the head from above, the differentiated tuberculations and lobulations on the 
metaterga, the porosteles, the well-developed cerategument on the metazonae, etc. However, only gonopod characters are decisive for a proper species determination.

This provides the first evidence of the presence of $M$. hastatus in the Caribbean.
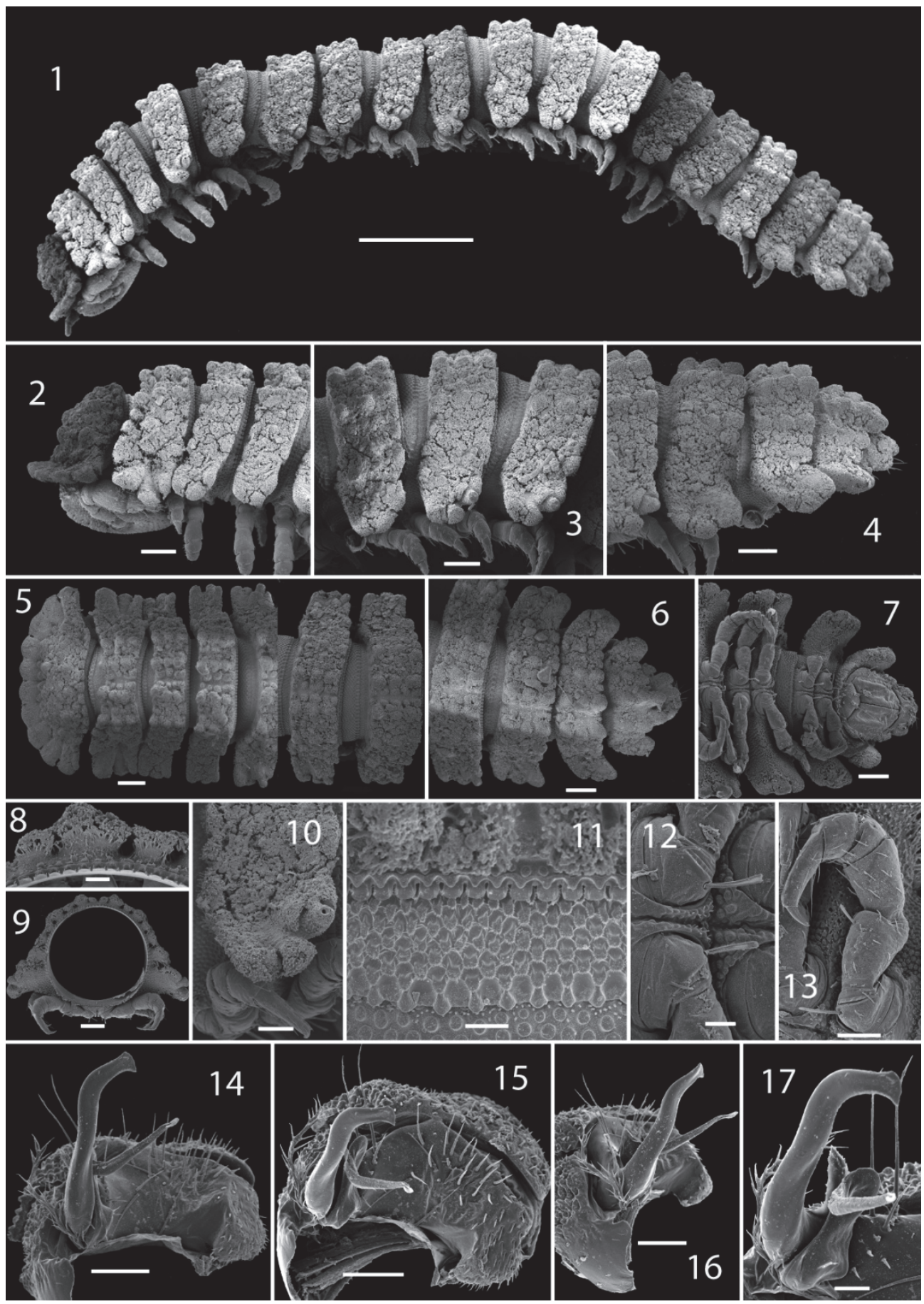
Figs 1-17. SEM micrographs of a male of Myrmecodesmus hastatus (SCHUBART, 1945), from Saint-Pierre, Martinique: habitus, lateral view (1); anterior part of body, lateral and dorsal views, respectively (2 \& 5); midbody segments, lateral view (3); caudal part of body, lateral, dorsal and ventral views, respectively (4, 6 \& 7); metatergal microsculpture, caudal view (8); cross-section of a midbody segment, caudal view (9); midbody paratergite, lateral view (10); tergal microsculpture with limbus, dorsal view (11); midbody sternite, ventral view (12); midbody leg, lateral view (13); left gonopod, submesal, subventral, subcaudal and mesal views, respectively (14-17). Scale bars: 0.5 $\mathrm{mm}(1), 0.1 \mathrm{~mm}(2-7 \& 9), 0.05 \mathrm{~mm}(10 \& 13-13), 0.02 \mathrm{~mm}(8,11 \& 12)$.

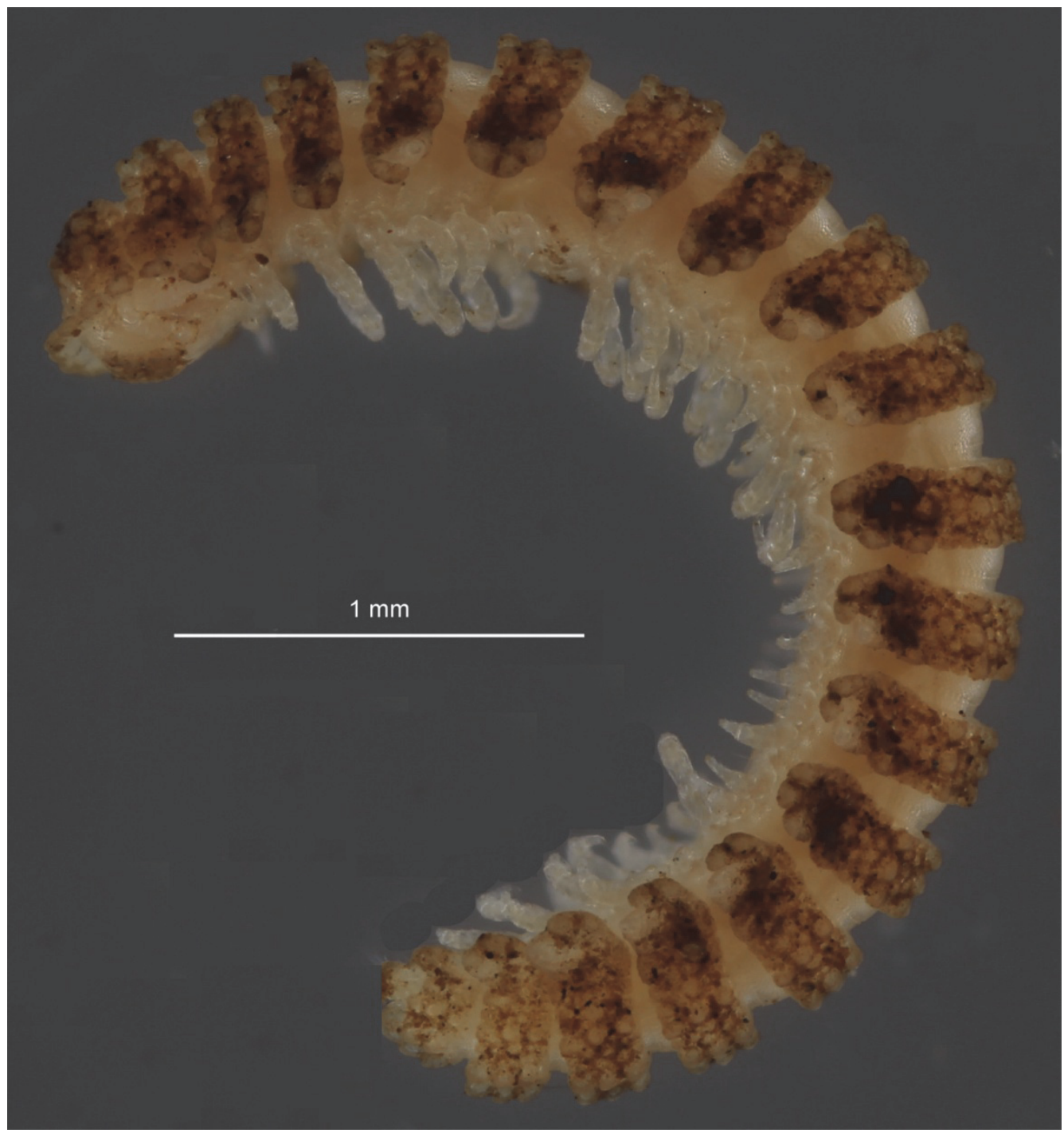

Fig. 18. Habitus of a male of Myrmecodesmus hastatus (Schubart, 1945), from Saint-Pierre, Martinique, lateral view. Picture by D. VandenSpiegel. 


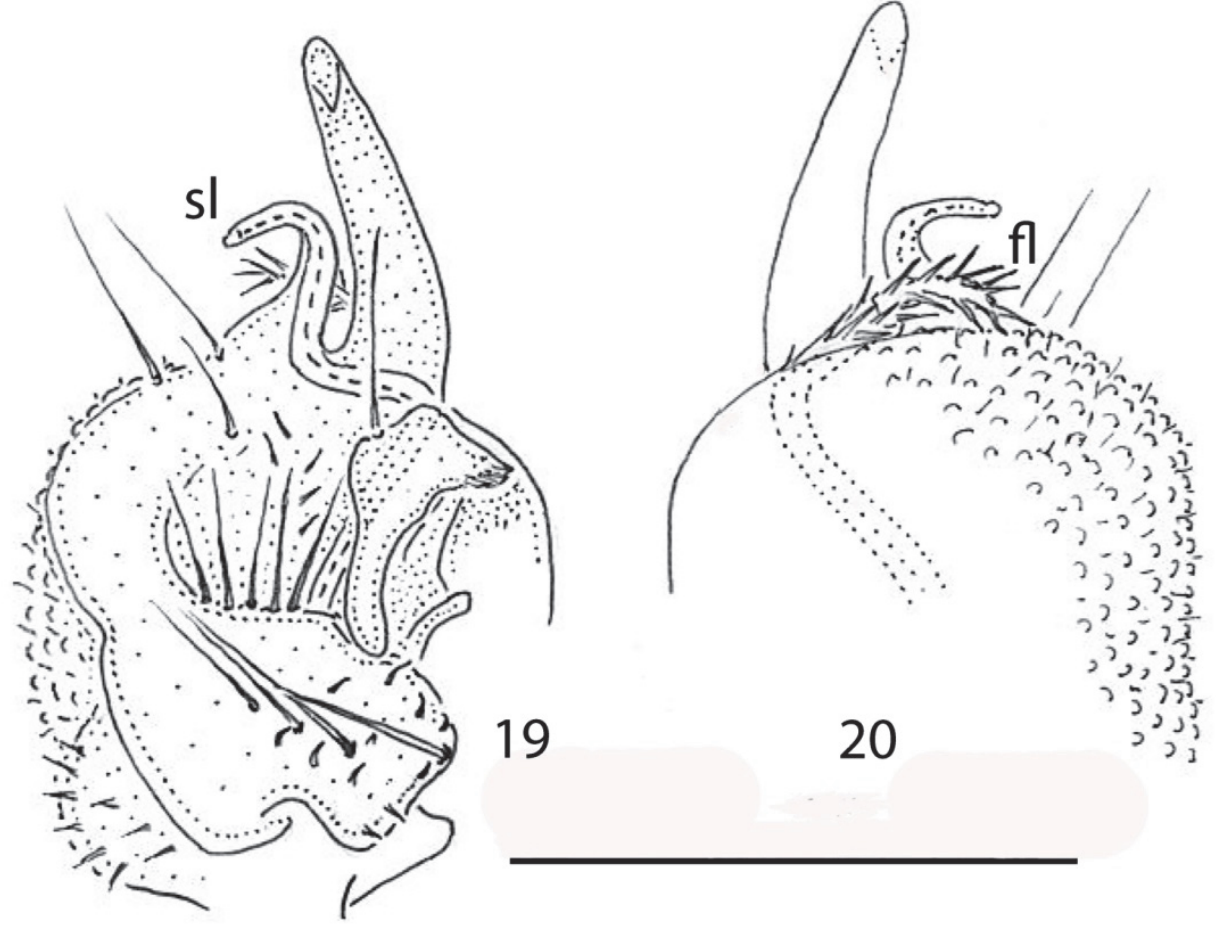

Figs 19 \& 20. Right gonopod of a male of Myrmecodesmus hastatus (Schubart, 1945), from Saint-Pierre, Martinique, subventral and subdorsal views, respectively. Scale bar: $0.2 \mathrm{~mm}$. Del. S. Golovatch.

Designations: fl - flagellum; sl - solenomere.

\section{ACKNOWLEDGEMENTS}

The first author is again deeply obliged to the Administration of the Muséum national d'Histoire naturelle, Paris, France for the opportunity to work at the Museum, this time in April 2016.

\section{REFERENCES}

Golovatch S. I. 2000 (for 1999). On six new and some older Pyrgodesmidae from the environs of Manaus, Central Amazonia, Brazil (Diplopoda, Polydesmida). Amazoniana 15 (3/4): 221-238.

Golovatch S. I. \& ADIS J. 2004. Myrmecodesmus hastatus (Schubart, 1945), a widespread Neotropical millipede (Diplopoda, Polydesmida, Pyrgodesmidae). Fragmenta Faunistica 47 (1): 35-38.

HofFMAN R. L. 1999. Checklist of the millipeds of North and Middle America. Virginia Museum of Natural History Special Publication Number 8, Martinsville, 584 pp.

SchuBART O. 1945. Os Proterospermophora do Distrito Federal (Myriapoda, Diplopoda). Arquivos do Museu Nacional, Rio de Janeiro, 38: 1-156.

SChUBART O. 1947. O elemento "sinanthropo" e estrangeiro entre os Diplopoda do Brasil. Arthropoda 1 (1): $23-40$.

SChubart O. 1954. Diplópodos argentinos del Museo de la Ciudad Eva Perón. III. Fam. Stylodesmidae, IV. Fam. Cryptodesmidae, V. Fam. Polydesmidae. Notas del Museo, Faculdad de Ciencias Naturales y Museo, Universidad Nacional de Eva Perón, 17 (155): 347-358.

Shelley R. M. 2004. The millipede family Pyrgodesmidae in the continental United States, with the first record of Poratia digitata (Porat) from the Bahamas (Diplopoda: Polydesmida). Journal of Natural History 38: 1159-1181.

Silvestri F. 1947. Contributo alla conoscenza dei diplopodi temitofili dell'America meridionale. Bollettino del Laboratorio di Entomologia Agraria di Portici 8: 1-32. 


\section{STRESZCZENIE}

[Szczegółowa ikonografia krocionoga Myrmecodesmus hastatus (Schubart, 1945) szerokorozprzestrzenionego w Neotropiku i pierwsze stwierdzenie tego gatunku w obszarze Karaibów (Diplopoda, Polydesmida, Pyrgodesmidae)]

Niepozorny krocionóg Myrmecodesmus hastatus (Schubart, 1945), który wydaje sie być silnie związany $\mathrm{z}$ gniazdami mrówek oraz termitów, występuje na większości obszarów Ameryki Południowej, a obecnie został stwierdzonyny na Martynice. W artykule zaprezentowano szczegółową ikonografię gatunku z licznymi ilustracjami spod mikroskopu skaningowego, umożliwiające identyfikację krocionoga. Stwierdzenie $M$. hastatus na Martynice znacznie rozszerza zasięg jego występowania, obejmujący także Antyle. 